EUROPA REGIONUM TOM XXVIII ROK 2016

DOI: $10.18276 /$ er.2016.28-14

AGNIESZKA MĄKOSZA, ESTERA TARASEWICZ

Zachodniopomorski Uniwersytet Technologiczny w Szczecinie

\title{
Potencjał turystyczny i rekreacyjny gminy Cedynia
}

\section{Wprowadzenie}

$\mathrm{T}$

urystyka i rekreacja stanowią ważny element w życiu coraz większej grupy społeczeństwa. Zauważyć można różną intensyfikację tych zjawisk na poszczególnych terenach Polski. Najbardziej uprzywilejowane pod tym względem są obszary morskie i górskie, oraz pojezierne. Obszary przygraniczne natomiast mają często charakter peryferyjny, wiejski, bez perspektyw gospodarczych $\mathrm{z}$ bardzo słabo rozwiniętym przemysłem.

Wśród wielu dostępnych definicji turystyki znajdujemy odwołanie do turystyki odbywająccj się z wykorzystaniem granic administracyjnych danego obszaru, zwanej turystyką przygraniczną lub transgraniczną. Turystyka transgraniczna dotyczy obszarów po obu stronach krajów graniczących ze sobą. Należy zwrócić uwagę, iż w tym przypadku przebycie granicy jest nieodłączną i charakterystyczną częścią, podczas gdy turystyka przygraniczna proponuje, lecz nie wymaga dokonania tego kroku (Więckowski 2010). Turystyka transgraniczna według Studzienieckiego (2003, 2004) oznacza turystykę wewnątrz regionu transgranicznego, której motywację stanowi produkt turystyczny tego regionu.

Aby mogła zaistnieć turystyka jako zjawisko na danym terenie, obszar ten musi wykazywać pewne właściwości, które literatura określa jako potencjał czy zasób stanowiący podstawę rozwoju turystyki. Potencjał turystyczny obejmuje wszelkie zasoby strukturalne i funkcjonalne warunkujące rozwój turystyki na 
danym terenie (Kaczmarka i in. 2005; Balińska 2008; Gabryjończyk 2009; Tucki 2009; Meyer 2010). Według Wyrzykowskiego (2010) o potencjale turystycznym, rozpatrywanym w aspekcie geograficznym (przestrzennym), decydują trzy czynniki - ranga walorów turystycznych, stopień dostępności komunikacyjnej oraz stan zagospodarowania turystycznego. Z kolei wykorzystanie potencjału turystycznego w tworzeniu produktów turystycznych jest jednym ze sposobów podnoszenia atrakcyjności obszaru (Zdon-Korzeniowska 2009). Hajduk (2007) stwierdza, iz szlaki turystyczne jako jedna z form produktu turystyczne, są bardzo ważnym elementem współpracy obszarów transgranicznych. Transgraniczne szlaki turystyczne są trasami biegnącymi przez terytoria przygraniczne sąsiadujących ze sobą państw. Mają za zadanie wspierać rozwój przyjaznych dla środowiska typów turystyki na obszarach przygranicznych. Szlaki te mają stanowić rodzaj promocji terenów transgranicznych, a także poszerzać horyzonty krajoznawcze i edukacyjne, mogą być również jedną z determinant wzrostu gospodarczego dla tych obszarów.

Warto więc podjąć działania prowadzące do rozwoju funkcji turystycznej i promujące obszary przygraniczne poprzez chociażby rozwój istniejących i propozycję nowych produktów turystycznych, na przykład w formie rowerowego szlaku transgranicznego, wykorzystujących lokalne zasoby.

\section{Materiał i metody}

Gmina miejsko-wiejska Cedynia (rys. 1) zajmuje łączną powierzchnię $180,38 \mathrm{~km}^{2}$, przy czym lasy stanowią ok. 44\%, a uprawy ok. $13 \%$. Według danych GUS na koniec 2015 roku liczba mieszkańców wynosiła 4350 osób, a gęstość zaludnienia to 24 osoby na $\mathrm{km}^{2}$.

Kierując się, podawaną przez Więckowskiego (2010) definicją, że obszary przygraniczne to tereny $\mathrm{w}$ odległości ok. $50 \mathrm{~km}$ od granicy w głąb kraju, do zaproponowania transgranicznego szlaku jako produktu turystycznego ograniczono się właśnie do takiej odległości odnosząc się do współpracy z niemieckimi powiatami: Uckermark, Barnim oraz Märkisch-Oderland.

Podstawą do przeprowadzenia analizy były materiały kartograficzne pochodzące z Urzędu Marszałkowskiego Województwa Zachodniopomorskiego oraz informacje z Banku Danych Lokalnych z lat 1997-2015. 


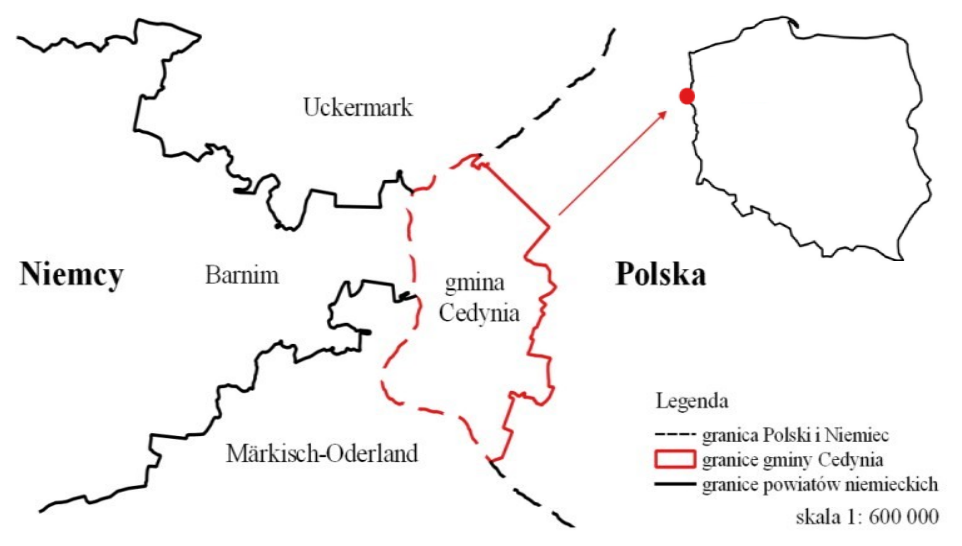

Rysunek. 1 Położenie gminy Cedynia

Wykonując analizę oceny potencjału turystycznego i rekreacyjnego zasobów strukturalnych wzorowano się na przekształconej metodzie optymalizacji zwanej inaczej metodą fizjografii urbanistycznej polegającej na rozpoznaniu konkretnych składników potencjału turystycznego, umieszczenie ich na mapach tematycznych i ocena z punktu widzenia form turystyki. Tak powstałe mapy są podstawą do wydzielenia zarówno obszarów najbardziej użytecznych jak i nieużytecznych dla turystyki (Zajadacz i Śniadek 2009).

$\mathrm{W}$ pracy analizowano, zgodnie $\mathrm{z}$ opisaną metodyką, walory naturalne, walory antropogeniczne i infrastrukturę turystyczną, dla których przyjęto następującą skalę: I - obszary bardzo korzystne, II - obszary korzystne; III - obszary mało korzystne. Opracowanie graficzne wykonano za pomocą programów QGIS 2.8.2 i Google Earth.

\section{Analiza wyników i dyskusja}

\subsection{Walory naturalne}

Ukształtowanie terenu ma charakter polodowcowy, czego dowodem są liczne wzgórza morenowe, pagórki, wysokie brzegi Doliny Odrzańskiej oraz piaszczyste równiny. Południową część gminy zajmują stoki wzgórz morenowych, z których kilka ma wysokość powyżej 100 m n.p.m., oraz sandry, natomiast północną wysoczyzny morenowe. Na załączonej mapie (rys. 2) widoczne są liczne zbiorniki wodne, które także należą do form polodowcowych. Zróżnicowane pod względem wielkości oraz linii brzegowej jeziora oraz oczka wodne 
występują głównie we wschodniej części gminy. Najistotniejszym jest jednak zbiornik wodny rzeki Odry na północnym-zachodzie, który stanowi ok. 3\% całkowitej powierzchni. Mniejsze cieki wodne występują jedynie w części południowej oraz północno-środkowej. Gęsta sieć rowów i kanałów melioracyjnych, przecinająca teren gminy szczególnie w części środkowo-zachodniej korzystnie wpływa na poprawę estetyki krajobrazu i stanowi cenny walor siedliskowy. Walory te potęguje występowanie mokradeł - największe w południowej części gminy, wokół dopływów Odry. Stwierdzono, iż całkowita suma wód powierzchniowych gminy Cedynia stanowi ok. $15 \%$ powierzchni terenu.

Na rys. 2a przedstawiono podział gminy na trzy części: północną i południową pokrytą terenami leśnymi i zadrzewionymi oraz środkową stanowiącą obszary użytkowane rolniczo. Na znacznej części gminy występują lasy, których występowanie związane jest z pagórkowatym ukształtowaniem terenu oraz piaszczystymi glebami. Duże powierzchnie leśne stanowią ważny zasób naturalny i turystyczny, dlatego też zostały objęte ochroną prawną. Cedyński Park Krajobrazowy zajmuje $75 \%$ powierzchni gminy, a resztę (25\%) stanowi jego otulina. Zatem przyroda stanowi cenne bogactwo gminy. Kolejną formą ochrony prawnej są rezerwaty przyrody usytuowane w zachodniej części gminy. Można tu wyróżnić położony najbardziej na północ leśno-stepowy rezerwat Bielinek o powierzchni 75,5 ha, który ciągnie się wąskim pasem wzdłuż prawego brzegu rowu wpadającego do Odry. Nieco niżej znajdują się dwa rezerwaty leśne - Olszyna Źródliskowa oraz Dolina Świergotki o powierzchniach odpowiednio 1 ha i 11 ha. Najdalej na południe wysunięty jest ostatni z rezerwatów Wrzosowiska Cedyńskie o powierzchni 71,61 ha chroniący unikalne wrzosowiska, murawy kserotermiczne oraz murawy napiaskowe ${ }^{1}$. Teren gminy w niemal $80 \%$ objęty jest także programem Natura 2000 dotyczącym obszarów ptasich w tym $20 \%$, to jednocześnie chronione obszary siedliskowe ${ }^{2}$.

$\mathrm{Z}$ przeprowadzonej analizy wynika, iż zdecydowaną przewagę powierzchniową mają obszary o bardzo korzystnych walorach naturalnych, zajmując ok. $60 \%$ całkowitej powierzchni gminy. Największy obszar o bardzo korzystnych warunkach naturahnych rozciąga się od południowej części lasu, wzdłuż Odry poprzez pótnocne tereny leśne kończąc na wschodnich obszarach zbiorników wodnych. Drugą część obszarów o bardzo korzystnych warunkach naturalnych

\footnotetext{
${ }^{1} \mathrm{http} / / /$ www.zpkwz.pl/parki-krajobrazowe/cedyski-park-krajobrazowy/ (dostęp 10.10.2016 r.)

${ }^{2} \mathrm{http}$ ://geoserwis.gdos.gov.pl/mapy (dostęp 10.10.2016 r.)
} 
stanowi rezerwat przyrody Wrzosowiska Cedyńskie oraz pas zieleni wysokiej na północny-wschód od rezerwatu. Korzystne warunki wykazują natomiast obszary znajdujące się głównie w zachodniej części gminy i zajmują ok. 30\% powierzchni. Obszary należące do ostatniej klasy - mało korzystnych - występują w szerokim pasie pomiędzy południowymi granicami gminy, nieco ponad dopływami Odry oraz w północnym fragmencie gminy. Zajmują 10\% obszaru gminy.
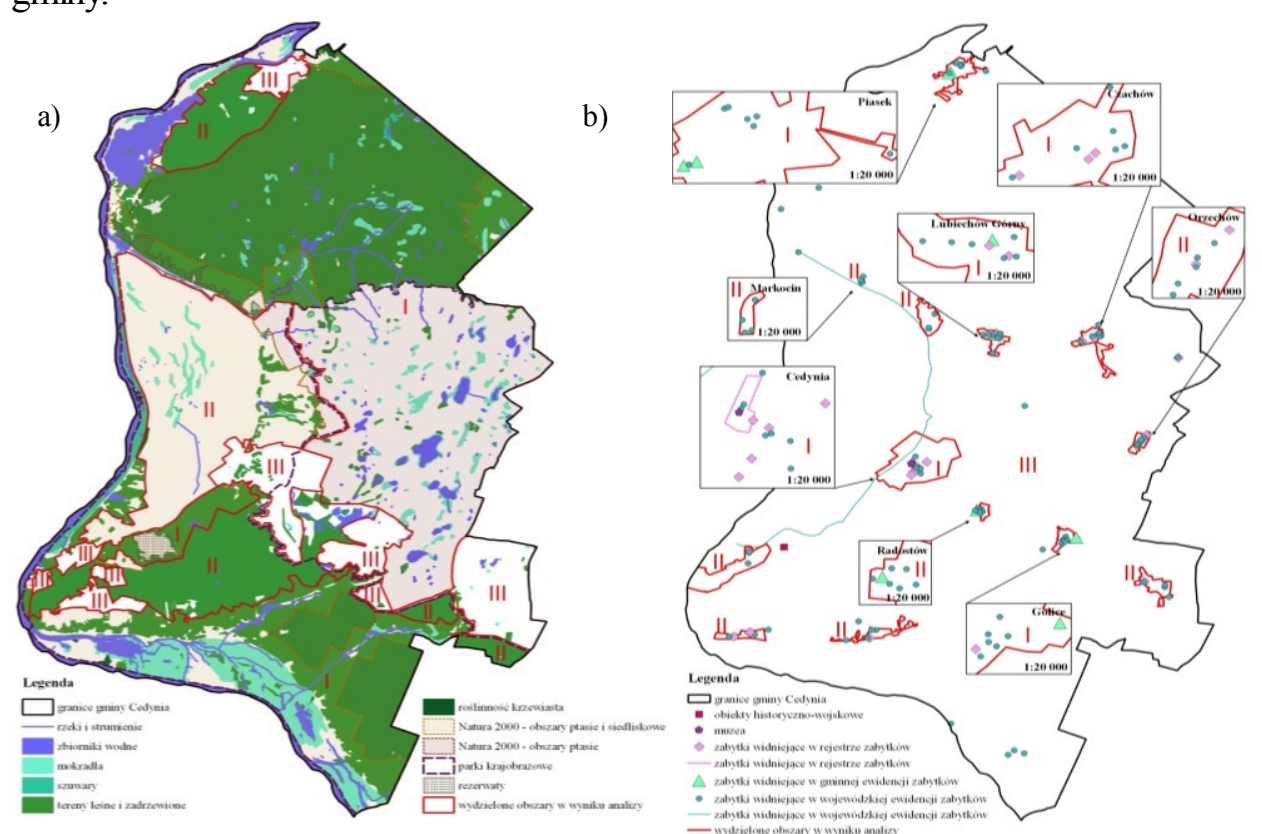

Rysunek 2. Mapa walorów naturalnych (a) i antropogenicznych (b) gminy Cedynia

\subsection{Walory antropogeniczne}

W wielu przypadkach największym zasobem obszarów przygranicznych są właśnie walory naturalne, głównie środowisko przyrodnicze, które mają istotne znaczenie dla turystycznego wykorzystania takiego obszaru. Te cenne walory przyrodnicze wraz z kulturowymi, budząc zainteresowanie turystów z sąsiednich państw, przyczyniają się do rozwoju specyficznych form turystyki krótkookresowej zwłaszcza krajoznawczej czy poznawczej (Więckowski 2010).

Walory antropogeniczne inaczej zwane kulturowymi to jak podaje Lijewski i in. (2008) obiekty wytworzone przez człowieka mające szczególne znaczenie dla turystyki np.: zabytki architektury i budownictwa, obiekty historyczno- 
-wojskowe, muzea martyrologii, zabytki techniki i przemysłu, ośrodki twórczości ludowej, współczesne imprezy kulturalne, miejsca pielgrzymkowe, muzea, zabytki archeologiczne. Na podstawie sporządzonej mapy (rys. 2b) przedstawiającej rozmieszczenie walorów antropogenicznych stwierdzono, iż z wymienionych powyżej grup w gminie występują jedynie zabytki archeologiczne, muzeum oraz obiekt historyczno-wojskowy.

Praktycznie wszystkie walory zlokalizowane są w granicach zabudowy poszczególnych miejscowości. Wyjątkiem jest Kanał Ulgi Polderu Cedyńskiego (Polder Cedyński), który ciągnie się od Bielinka, poprzez Lubiechów Dolny i Cedynię do Osinowa Dolnego. Najwięcej walorów antropogenicznych znajduje się w Cedyni, praktycznie w samym jej centrum. Na 21 wszystkich miejscowości w gminie tylko 4 nie mają żadnego historycznego obiektu, są to: Barcie, Parchnica, Piasecznik oraz Trzypole. Jedynym muzeum działającym od $1966 \mathrm{r}$. jest znajdujące się w Cedyni Muzeum Regionalne, którego wystawa nawiązuje do historycznej bitwy pod Cedynią oraz lokalnego dziedzictwa kulturowego ${ }^{3}$. Przeprowadzona analiza wskazała na liczne występowanie cmentarzy, szczególnie przykościelnych (we wsi Stara Rudnica jest to cmentarz ewangelicki). Zdaniem Awramiuk-Godun (2013) i Szczęsnej (2010), obecność zabytkowych obiektów sakralnych charakterystyczna jest właśnie dla polskich obszarów przygranicznych.

Zgodnie z przyjętą metodą wyodrębniono 5 bardzo korzystnych obszarów zajmujących ok. 5\% powierzchni gminy, 8 o warunkach korzystnych i powierzchni ok. $10 \%$ oraz 1 obszar mało korzystny stanowiący największą pozostałą część terenu. Przeprowadzona analiza wykazała, że liczne i bogate walory antropogeniczne w gminie Cedynia są jednak bardzo skoncentrowane punktowo.

\subsection{Infrastruktura turystyczna}

Nieodłącznym elementem istnienia i rozwoju turystyki na danym obszarze jest infrastruktura turystyczna (Bański 2014; Niedziółka 2011). Na potrzeby analizy istniejącej infrastruktury turystycznej gminy Cedynia wykonano mapę (rys. 3a) przedstawiającą rozmieszczenie jej elementów w przestrzeni. Można zaobserwować, zdecydowanie dużą koncentrację zjawiska tylko w dwóch miejscach: mieście Cedynia oraz wsi Osinów Dolny. Spośród obiektów stanowiących bazę noclegową wyróżniamy: 3 hotele, dom gościnny, pensjonat, ranczo,

${ }^{3} \mathrm{http}: / /$ www.cedynia.pl/, (dostęp 10.10.2016 r.). 
obiekt oferujący pokoje gościnne oraz gospodarstwo agroturystyczne, rozmieszczone w 5 miejscowościach. Cztery spośród nich posiadają w ofercie opcję noclegu z wyżywieniem. Baza gastronomiczna zlokalizowana jest jedynie we wcześniej wspomnianych miejscowościach. W Cedyni występuje 7 restauracji z czego 4 przy obiektach noclegowych, a w Osinowie Dolnym 2 restauracje. Na całą gminę przypada 14 sklepów spożywczych, w tym 7 w Cedyni i 3 w Osinowie Dolnym oraz 3 targowiska. Elementy bazy uzupełniającej takie jak: centrum handlowo-usługowe, ośrodek sportowo-rekreacyjny, poczta, biblioteka, przychodnia, 2 apteki oraz 3 banki zlokalizowane są w siedzibie gminy. W całym terenie istnieją 2 bankomaty, jeden w Osinowie Dolnym, drugi w Cedyni. Jedyny parking znajduje się przy Górze Czcibora.

Stwierdzono, że istniejąca komunikacja wewnątrz gminy jak i z obszarami graniczącymi nie spełnia nawet minimum wymagań (rys. 3a). Nie istnieje tu żadna stacja lub przystanek kolejowy, więc nie ma możliwości bezpośrednich dojazdów pociągami. Jedynym przewoźnikiem obsługującym połączenie gminy Cedynia z sąsiadującą Chojną, w której istnieje dworzec kolejowy jest PKS Myślibórz Sp. z o.o. Opisana sytuacja komunikacyjna pozwala przypuszczać, że dla turystów, ale też osób mieszkających w niedalekiej odległości i nieplanujących noclegów, stanowi to pewną niedogodność. Zdecydowanie lepiej przedstawia się sytuacja dla podróżujących własnymi samochodami lub dla zorganizowanych wycieczek poruszających się autokarami. Gminę przecinają 3 drogi wojewódzkie (124, 125 i 126). Pierwsza z nich ciągnie się od Osinowa Dolnego, poprzez Cedynię, aż do Chojny, dzieląc teren na północną i południową część. Kolejna zaczynając od wsi Piasek biegnie pionowo w dół do Cedyni, następnie skręca w lewo i przez Golice trafia do sąsiedniej gminy Moryń. Ostatnia z dróg prowadzi z Osinowa Dolnego wzdłuż południowo-zachodniej granicy przez wieś Siekierki do gminy Mieszkowice. Z Osinowa Dolnego istnieje również dobre połączenie niemiecką drogą krajową nr 158 z Berlinem.

Można zauważyć, iż bardzo korzystne i korzystne obszary zajmują jedynie ok. $2 \%$ powierzchni gminy. Należy jednak pamiętać o specyficznym wiejskim i przygranicznym charakterze gminy, który nadaje się do wykorzystania dla uprawiania krótkoterminowej turystyki krajoznawczej. Istniejąca infrastruktura nie zaburza naturalnego krajobrazu, nie wpływa również w znacznym stopniu na otaczającą przyrodę i tereny chronione. 

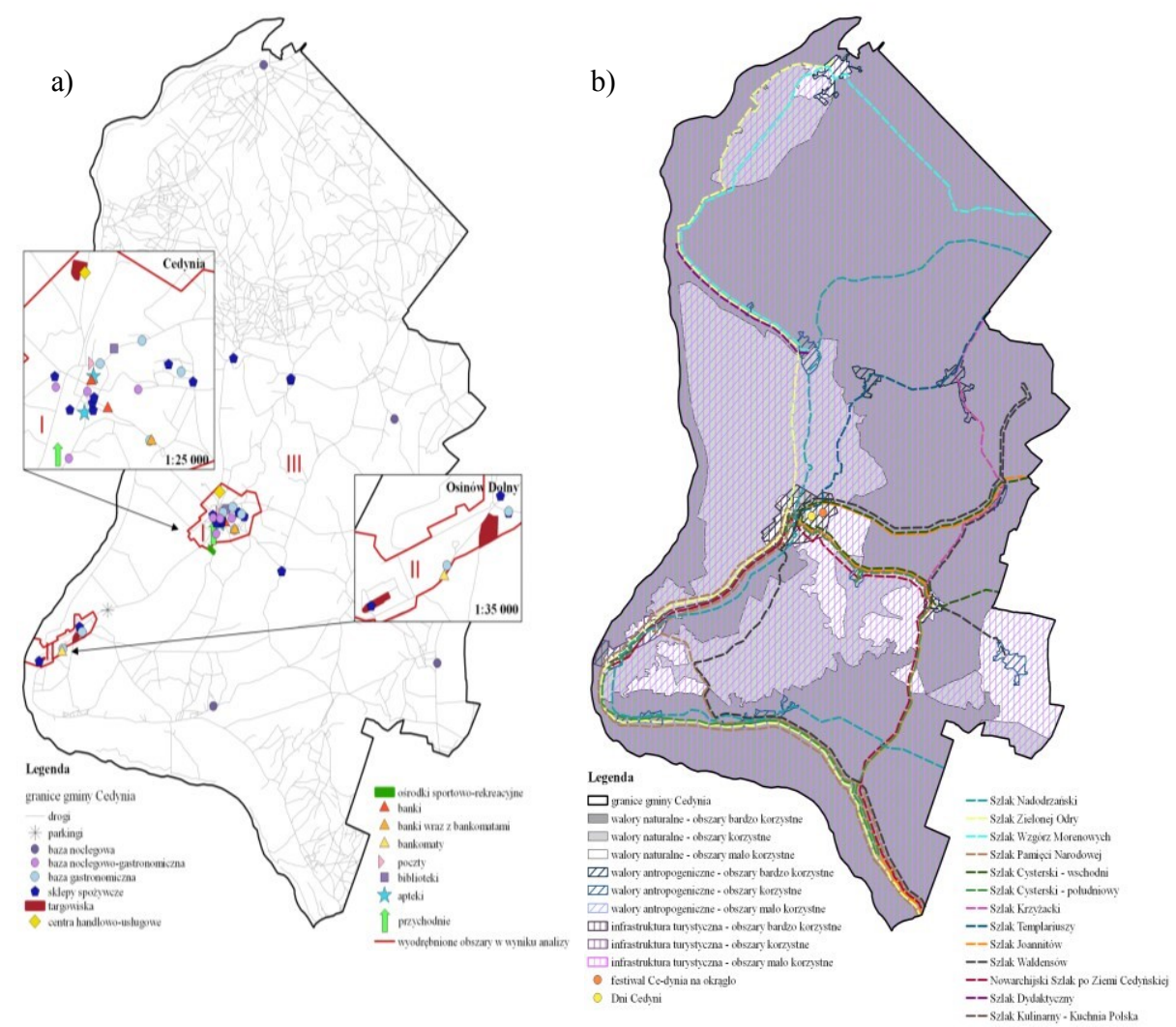

Rysunek 3. Mapa infrastruktury (a) turystycznej gminy Cedynia oraz istniejących produktów (b) turystycznych

\subsection{Charakterystyka istniejących produktów turystycznych}

$\mathrm{Na}$ rys. $3 \mathrm{~b}$ przedstawiono rozmieszczenie i przebieg istniejących produktów turystycznych liniowych (np.: Szlak Pamięci Narodowej, Szlak Templariuszy) i punktowych (np.: festiwal „Ce-dynia na okrągło”) gminy Cedynia. Widocznym jest, że walory naturalne oraz antropogeniczne mają tu kluczowe znaczenie. Wykonana analiza poszczególnych elementów, której wynikiem jest podział powierzchni gminy Cedynia na obszary bardzo korzystne, korzystne oraz mało korzystne jest zgodna $\mathrm{z}$ trasami istniejących szlaków turystycznych, oraz produktów punktowych. Szlaki turystyczne przebiegają wzdłuż wydzielonych najkorzystniejszych obszarów z pominięciem powierzchni mało korzystnych. 
W gminie Cedynia istnieje 13 szlaków tematycznych o różnym stopniu trudności. Organizowane są dwie cykliczne imprezy w ciągu roku (rys. 3b). Największe zagęszczenie szlaków występuje w południowej części gminy, przebiegają one przez takie miejscowości jak: Siekierki, Stara Rudnica, Stary Kostrzynek, Osinów Dolny oraz Cedynię. Dwa najdłuższe z nich to Szlak Zielonej Odry i Nadodrzański, które biegną praktycznie przez całą długość gminy. Najkrótszym i zarazem najoryginalniejszym szlakiem jest Szlak Kulinarny - Kuchnia Polska łączący tylko dwie miejscowości, a mianowicie Cedynię i Osinów Dolny. Jego zadaniem jest zwrócenie uwagi turystów na możliwość skosztowania regionalnych dań ziemi cedyńskiej. W Cedyni latem i jesienią odbywają się dwie imprezy okolicznościowe. Pierwsza to „Dni Cedyni” skierowane nie tylko do mieszkańców, ale i przyjeżdżających turystów, druga natomiast to festiwal „Ce-dynia na okrągło” - pierwszy raz odbył się w październiku 2015 r. i dotyczył zdrowego stylu odżywiania się ${ }^{4}$.

Przedstawione istniejące już produkty turystyczne, głównie szlaki, nie pozwalają w pełni wykorzystać przygranicznej lokalizacji gminy. Przy tak atrakcyjnych walorach zarówno przyrodniczych jak i antropogenicznych wskazanym byłoby wyznaczenie nowego produktu turystycznego w postaci szlaku turystycznego, połączonego z obszarami sąsiednich Niemiec.

\section{Transgraniczny szlak turystyczny - potencjalny produkt tury- styczny gminy Cedynia}

Zgodnie z wytycznymi powstały dwa obszary o bardzo korzystnych warunkach zajmujące łącznie ok. $60 \%$ całkowitej powierzchni, sześć o korzystnych stanowiących ok. 30\% terenu oraz osiem o średnio korzystnych położonych na ok. $10 \%$ gminy. Pierwsze $\mathrm{z}$ nich zlokalizowane są w północno-wschodniej i południowej części, drugie głównie we wschodnim fragmencie, natomiast ostatnie usytuowane są $\mathrm{w}$ poziomym pasie pomiędzy granicami $\mathrm{w}$ południowym sektorze. Wykonany przegląd mocnych i słabych stron gminy Cedynia umożliwił wytyczenie proponowanego produktu turystycznego z ominięciem terenów najmniej interesujących, tym samym w miarę sposobności pozwalając na maksymalne wykorzystanie obszarów najcenniejszych.

${ }^{4}$ http://ckcedynia.pl/, (dostęp 10.10.2016 r.). 
Powstały produkt zlokalizowany jest zarówno po stronie polskiej jak i niemieckiej, jest szlakiem transgranicznym. Zaproponowana trasa rowerowa o długości ok. $270 \mathrm{~km}$ biegnie przez gminę Cedynia oraz trzy graniczące powiaty niemieckie: Uckermark, Barnim oraz Märkisch-Oderland - rys. 4a i 4b.

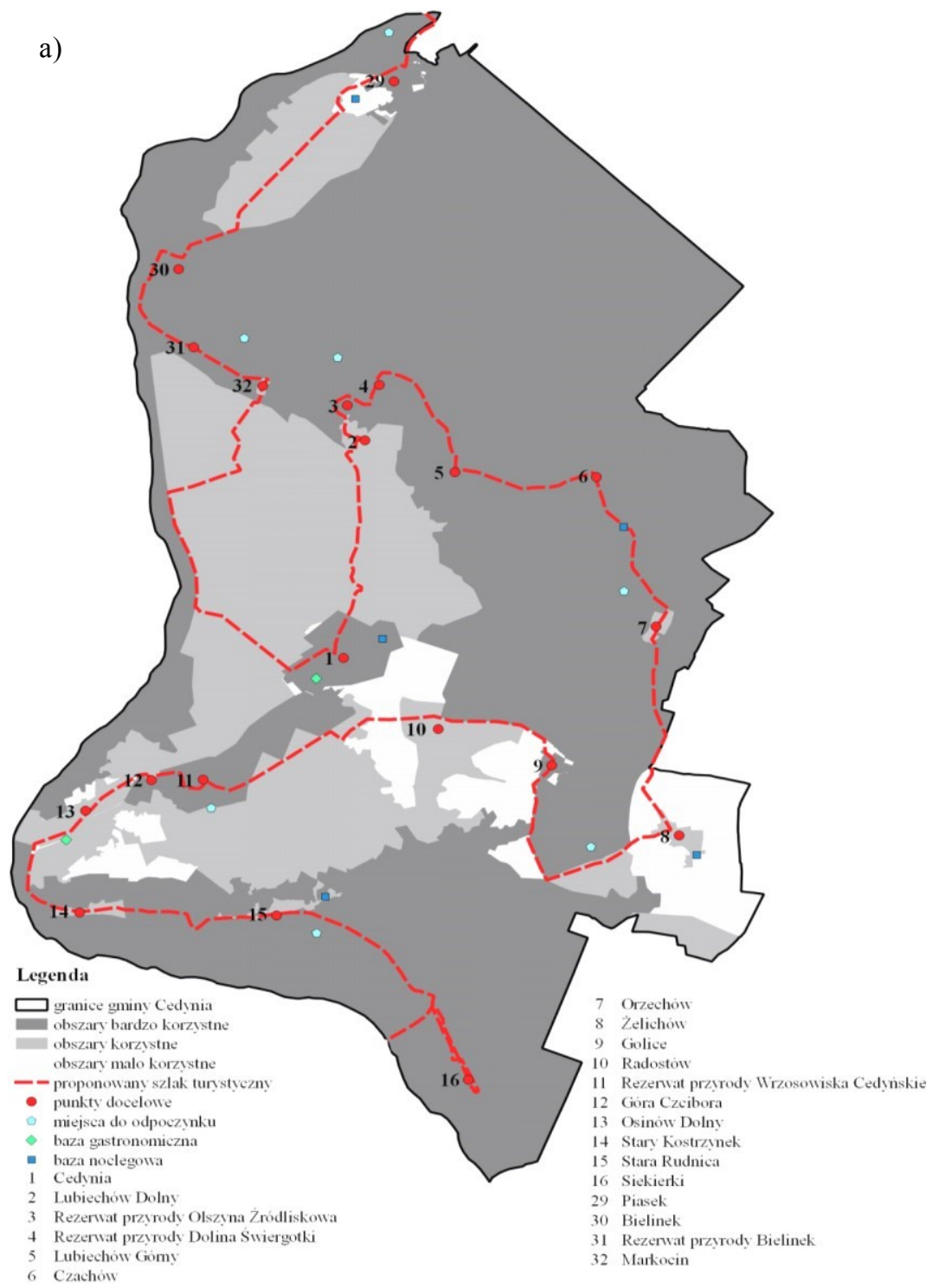

Rysunek. 4a. Propozycja rowerowego szlaku jako produktu transgranicznego przebieg na terenie gminy Cedynia 
b) powiat Uckermark

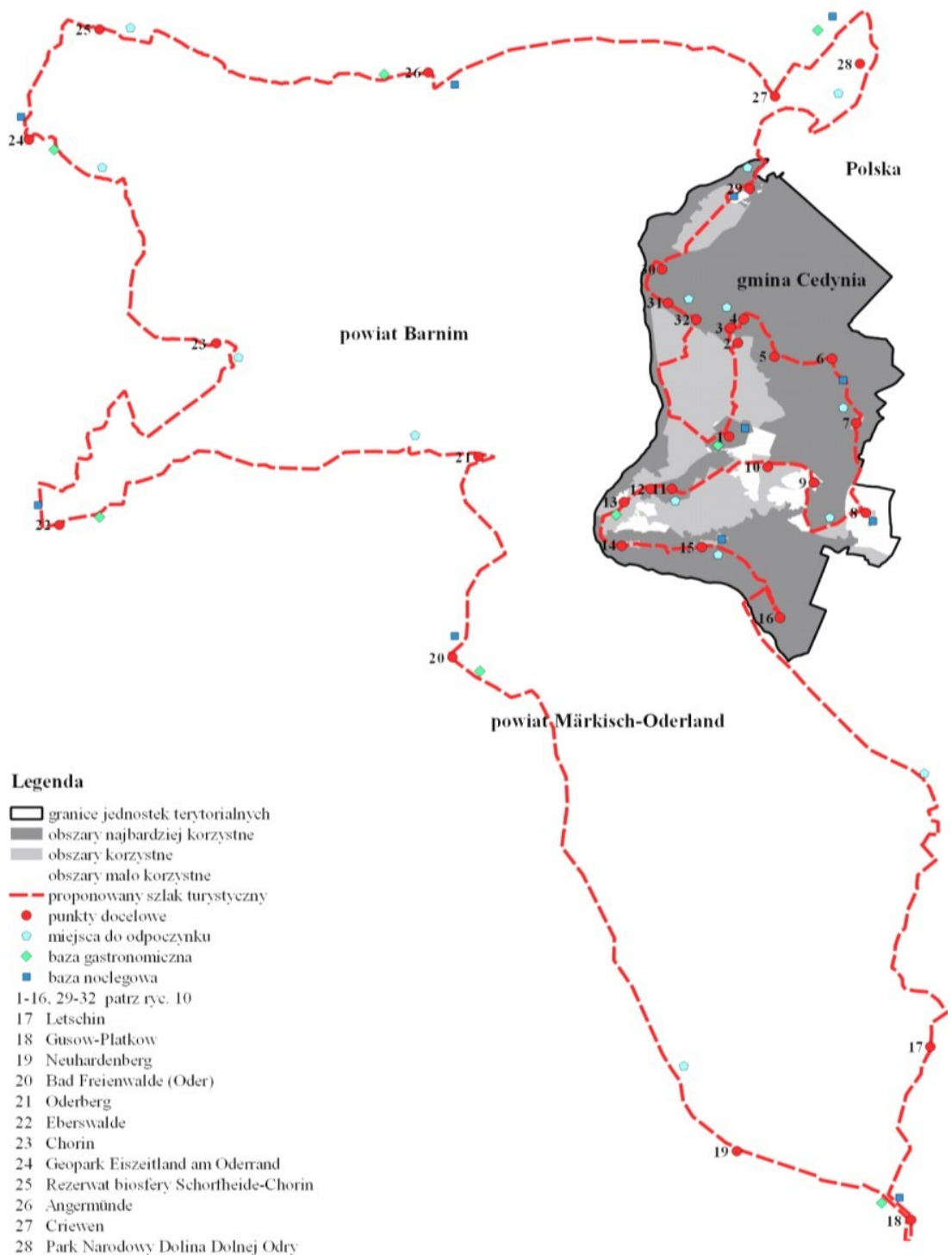

Rysunek. 4b. Propozycja rowerowego szlaku jako produktu transgranicznego przebieg na terenie gminy Cedynia (a) i schemat na obszarze Niemiec (b)

Szlak rozpoczyna się od Punktu Informacji Turystycznej w Cedyni gdzie można uzyskać informację o przebiegu całej trasy, najciekawszych obiektach. Dalej kierując się na północ wzdłuż Kanału Ulgi w kierunku skupiska trzech 
punktów docelowych jakimi są kolejno Lubiechów Dolny, Rezerwat przyrody Olszyna Źródliskowa oraz Rezerwat przyrody Dolina Świergotki. We wsi warto zwrócić uwagę na kościół rzymsko-katolicki p.w. Matki Bożej Różańcowej, natomiast na terenie drugiego $\mathrm{z}$ rezerwatów można odpocząć na specjalnie wyznaczonych zadaszonych siedziskach. Kolejno drogą leśną jedziemy do Lubiechowa Górnego, a następnie do wsi Czachów, gdzie podziwiamy wiejską oraz sakralną zabudowę. Przejeżdżamy przez Orzechów, Żelichów, Golice oraz Radostów. $\mathrm{Na}$ tym odcinku istnieją dwa miejsca przystankowe. Znajdują się tu także dwa obiekty noclegowe w Czachowie i Żelichowie. Następnie udając się śródleśną drogą $\mathrm{w}$ kierunku południowo-zachodnim docieramy do Rezerwatu przyrody Wrzosowiska Cedyńskie. Warto tu odpocząć przed wjazdem na pobliską Górę Czcibora - punkt widokowy. Dalej jadąc wzdłuż drogi nr 124, a później nr 126 przejeżdżamy przez Osinów Dolny, gdzie warto spróbować lokalnej kuchni. Następnie przez Starą Rudnicę, Stary Kostrzynek i Siekierki delektując się widokiem rozlewisk nadodrzańskich oraz tutejszą zabytkową architekturą. We wsi Stary Kostrzynek znajduje się obiekt noclegowy, a dla zmęczonych punkt przystankowy. W Siekierkach znajduję się przejście graniczne z zabytkowym mostem kolejowy ${ }^{5}$, po którym można częściowo przejechać drezyną i tym samym dostać się na teren powiatu Märkisch-Oderland, położonego w północno-wschodniej części Brandenburgii ${ }^{6}$ wyróżniającego się urokliwymi krajobrazami doskonale nadającymi się do wypoczynku i relaksu. Jadąc na południe wzdłuż Odry, oraz na południowy-zachód docieramy do położonego w Letschin muzeum oferujące eksponaty związane $z$ kolejnictwem i rolnictwem ${ }^{7}$. W dalszym etapie mamy Zamek Gusow ${ }^{8}$ i znajdujące się $w$ nim muzeum w miejscowości Gusow-Platkow, oraz zamek wraz z parkiem i pobliskimi budynkami w Neuhardenberg. Jadąc na pótnoc wzdłuż drogi nr 167 docieramy do uzdrowiskowego miasta Bad Freienwalde ${ }^{9} \mathrm{z}$ wieżą widokową na panoramę doliny Odry. W Gusow oraz Bad Freienwalde można skorzystać z noclegu, bądź bazy gastronomicznej. W dalszym etapie trasy dostajemy się do powiatu Barnim - pokrytego w ok. $46 \%$ przez lasy i w 5\% przez wody. Niewątpliwą atrakcją będzie tu

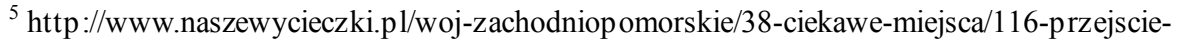
graniczne-brueckentaxi-przez-most-neuruednitz-siekierki, (dostęp 10.10.2016 r.).

$6 \mathrm{http}: / / w w w . m a e r k i s c h-o d e r l a n d . d e / c m s /$ front_content.php?idcat=224\&lang=1, (dostęp 10.10.2016 r.)

${ }^{7} \mathrm{http}: / /$ www.evl-letschin.de/Pages/default.aspx, (dostęp 10.10.2016 r.).

${ }^{8} \mathrm{http}: / /$ navtur.pl/place/show/1896,zamek-gusow, (dostęp 10.10.2016 r.).

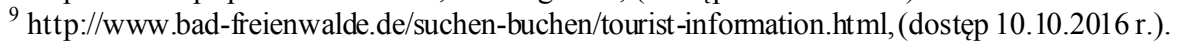


muzeum żeglugi śródlądowej Binnenschifffahrts-Museum w Oderberg z najcenniejszym eksponatem parowcem Riesa ${ }^{10}$. Udając się $w$ kierunku zachodnim dotrzeć można do Zoo w Eberswalde. Tutaj również znajduje się baza noclegowe i gastronomiczna. W drodze do powiatu Uckermark mamy stary Klasztor Cystersów w Chorin, Geopark „Eiszeitland am Oderrand“ w Joachimsthal chroniący bogato urozmaiconą, polodowcową rzeźbę terenu ${ }^{11}$ oraz Rezerwat biosfery Schorfheide-Chorin w tym multimedialne centrum Blumberger Mühle, gdzie na terenie 14 ha jest możliwe napawanie się unikalną przyrodą. Jadąc na wschód wkraczamy na teren powiatu Uckermark, a celem jest historyczne miasto Angermünde, uhonorowane $\mathrm{w}$ turnieju „Utrzymanie historycznych miejsc” $\mathrm{z}$ całym zapleczem infrastruktury turystycznej. Dalej mamy Park Narodowy Doliny Dolnej Odry zasobny w wiele gatunków ptaków wodnych. Powrót do Polski przez wieś Piasek, gdzie możemy skorzystać z odpoczynku lub noclegu w leśniczówce. Udając się w stronę południowego-zachodu trafiamy do Rezerwatu przyrody Bielinek. Przedostatnim punktem na mapie szlaku rowerowego jest niewielka wieś Markocin z zabytkową zabudową folwarczną. Następnie jadąc wśród terenów leśnych i nadrzecznych wracamy do Cedyni.

\section{Podsumowanie}

Otrzymane wyniki pokazały bardzo atrakcyjny obraz gminy pod względem przyrodniczym. Za sprawą Cedyńskiego Parku Krajobrazowego, obszarów Natura 2000 oraz obecności Odry aż $60 \%$ terenu gminy zaklasyfikowano jako bardzo dobre do rozwoju turystyki, szczególnie krajoznawczej, dotyczącej obcowania $\mathrm{z}$ unikatową przyrodą.

Podczas analizy walorów antropogenicznych gminy Cedynia stwierdzono, iż obszary o warunkach bardzo korzystnych występują tylko na 5\% powierzchni. Natomiast obszary bardzo korzystne i korzystne obejmują 15\% całkowitej powierzchni gminy, co jest wynikiem skoncentrowania występujących, tu aż 104 cennych obiektów antropogenicznych głównie w strefie zabudowanej i miejscowościach.

Analiza infrastruktury turystycznej gminy Cedynia wykazała koncentrację jej elementów w dwóch ośrodkach: Cedyni i Osinowie Dolnym. Pomimo, iż można wyróżnić tu jedynie ok. $2 \%$ obszarów bardzo korzystnych i korzystnych

\footnotetext{
${ }^{10} \mathrm{http}: / /$ www.bs-museum-oderberg.de/,(dostęp 10.10.2016 r.).

${ }^{11} \mathrm{http}: / /$ www.geopark-eiszeitland.de/,(dostępu 10.10.2016 r.).
} 
pod względem występowania infrastruktury, należy pamiętać, że wykazane walory naturalne i antropogeniczne predysponują obszar gminy przede wszystkim do turystyki krótkoterminowej, krajoznawczej.

Charakterystyka istniejących produktów turystycznych na terenie gminy ukazała dość rozbudowaną sieć szlaków turystycznych oraz dwie cykliczne imprezy. Jednak jak stwierdzono, nie wykorzystują one w pełni przygranicznego położenia gminy Cedynia.

$\mathrm{Na}$ podstawie wyznaczonych metodą optymalizacji obszarów bardzo korzystnych i korzystnych, zajmujących w sumie w gminie $90 \%$ powierzchni gminy Cedynia oraz na podstawie krótkiej ogólnej charakterystyki najciekawszych miejsc i istniejących szlaków na terenie Niemiec stworzono propozycję transgranicznego szlaku turystycznego o długości 270. Proponowany szlak ma za zadanie zwiększyć dostępność do gminy a tym samym regionu i istniejących atrakcji turystycznych, szczególnie dla turystów zagranicznych oraz przyczynić się do o wzmocnienia funkcji turystycznej i promocji gminy Cedynia jako ważnego punktu na mapie turystyki w strefie przygranicznej.

\section{Bibliografia}

Awramiuk-Godun A Krajobrazy pogranicza kulturowego. w: Prace komisji krajobrazu kulturowego, J. Plit (red.), Komisja krajobrazu kulturowego PTG, nr 19, Sosnowiec 2013, s. 62-72.

Bański J., Rola infrastruktury okołoturystycznej w rozwoju turystyki na obszarach wiejskich.w: Infrastruktura okołoturystyczna jako element wzbogacajacy ofertę obszarów wiejskich, C. Jastrzębski (red.), Wydawnictwo Wyższej Szkoły Ekonomii, Prawa i Nauk Medycznych w Kielcach, Kielce 2014, s 34-35.

Bosiacki S., Hołderna-Mielcarek B., Potencjat turystyczny Poznania jako podstawa kreowania produktów markowych. Zesz. Nauk. U S nr 591, Ekonomiczne problemy usług nr 53, Szczecin 2010, s. 39-53.

Chudy-Hyski D., Ocena wybranych uwarunkowań rozwoju funkcji turystycznej obszaru. w: Infrastruktura i ekologia terenów wiejskich, PAN, nr 2 (1), Kraków 2006, s. 129-141.

Gabryjończyk P., Potencjat turystyczny szlaku Polskich Zamków Gotyckich w województwie pomorskim - próba pomiaru i analizy. w: Potencjat turystyczny regionów, (red.) A. Balińskiej, Wydawnictwo SGGW i FAPA, Warszawa 2009, s. 9-20.

Hajduk S., Szlaki turystyczne jako element integracji regionów transgranicznych. w: Człowiek i środowisko, nr 31, 2007, s. 87-105

Kaczmarek J., Stasiak A., Włodarczyk B., Produkt turystyczny: pomyst, organizacja, zarządzanie. PWE, r. 2, Warszawa 2005. 
Kozak M., Konkurencyjność turystyczna polskich regionów. w: Studia Regionalne iLokalne, Centrum Europejskich Studiów Regionalnych i Lokalnych (EUROREG), nr 3 (25), Warszawa 2006.

Lijewski T., Mikułowski B., Wyrzykowski J., Geografia turystyczna Polski. PWE, 2008. Meyer B., Aktywność samorządu lokalnego jako element potencjału turystycznego na przykładzie wybranych gmin województwa zachodniopomorskiego. w: Potencjat turystyczny. Zagadnienia przestrzenne. Zesz. Nauk. nr 590, Ekonomiczne Problemy usług nr 52, US, Szczecin 2010, s.21-32.

Niedziółka A., Stan i uwarunkowania rozwoju infrastruktury turystycznej w gminie Ciężkowice, w: Infrastruktura i ekologia terenów wiejskich, PAN, nr 2, Kraków 2011, s. 99-109.

Studzieniecki T., Turystyka transgraniczna - próba definicji i interpretacji,w: Unia Europejska a przyszłość polskiej turystyki, SGH w Warszawie, Warszawa 2003, s. 317-330.

Studzieniecki T., Turystyka transgraniczna - nowa forma turystyki międzynarodowej w Europie, w: Rozwój obszarów przygranicznych w kontekście funkcjonowania euroregionów, PWSZ w Białej Podlaskiej, Biała Podlaska 2004, s. 173-183.

Szczęsna J., Wielokulturowa substancja zabytkowa w krajobrazie pogranicza Lubelszczyzny a możliwości jej wykorzystania dla rozwoju turystyki, w: Problemy Ekologii Krajobrazu, Problemy zagospodarowania, ochrony i monitoringu krajobrazów strefy przygranicznej. S. Horska-Schwarz (red.), Polska Asocjacja Ekologii Krajobrazu, Uniwersytet Wrocławski, t. XXVI, Wrocław 2010, s. 297-300.

Tucki A., Potencjat turystyczny regionu lubelskiego, Annales UMCS Sectio B, vol. LXIV.1, Lublin 2009, s. 15-35.

Więckowski M., Turystyka na obszarach przygranicznych Polski, PAN IGiPZ, Warszawa 2010, s. 12-13, 23-30, 70-82.

Wyrzykowski J., Potencjał turystyczny w ujęciu geograficznym. w: Potencjał turystyczny. Zagadnienia przestrzenne. Zesz. Nauk. US nr 590, Ekonomiczne problemy usług nr 52, Szczecin 2010.

Zajadacz A., Śniadek J., Ocena potencjału turystycznego, w: Uwarunkowania i plany rozwoju turystyki Z. Młynarczyka, A. Zajadacz (red.), Wydawnictwo Naukowe UAM, t. III, Poznań 2009, s. 50.

Zdon-Korzeniowska M., Jak ksztaltować regionalne produkty turystyczne? Teoria i praktyka. Wydawnictwo Naukowe Uniwersytetu Jagiellońskiego, Kraków 2009, s.127.

\section{Touristic and recreational potential of the Cedynia commune}

\section{Summary}

This document describes existing natural and anthropogenic qualities of a border commune of Cedynia, located within Gryfino county in West Pomeranian voivodship. A quality of tourist infrastructure in this area has also been analysed and on the bas is of those results a possibility of the growth of short-term tourism (mainly sightseeing tours) has been assessed. The purpose and the final effect of those analyses is a proposal of 
a tourist product, in this case the cross-border tourist trail, which exploits the proved qualities of the area and links the tourist's attractions of the region with the border German terrain. The results of this extracting shows how attractive the Cedynia commune is from the natural point of view. The Cedynski Landscape Park, Natura 2000 and Odra River make $60 \%$ of the commune's area a very beneficial for the growth of the shortterm tourism. From the anthropogenic point of view, only 5\% of the commune's area is classed as very beneficial and it mainly is a built-up area. Also the tourist infrastructure has only been located in two main centres - Cedynia and Osinow Dolny. The results of the optimization show that in total there is $90 \%$ of the very beneficial and beneficial areas in the Cedynia commune. Also on the bas is of the short, general characteristic of the most interesting places and existing trails on the German's side of the border, an idea of creating the border tourist trail has been proposed. The main purpose of this trail is the growth and expansion of tourism in the Cedynia commune and also an advertisement of Cedynia commune as an important place on the tourist map in the border area.

Translated by Agnieszka Mąkosza 